\title{
Yield, Yield Attributes and Economics of Wheat as Influenced by Resources Conservation and Nutrient Management Practices
}

\author{
Suborna Roy Choudhury*, Dipak Kumar Dipu, Nintu Mandal and \\ Sushil Kumar Pathak
}

Department of Agronomy, Bihar Agricultural University, Sabour, Bhagalpur, Bihar, India

*Corresponding author: subornabau@gmail.com

Received: 10 Sept., 2020

Revised: 21 Nov., 2020

Accepted: 14 Dec., 2020

\begin{abstract}
A field study was conducted during rabi season of consecutive two years i.e. 2014-15 and 2015-16 at university farm at Bihar Agricultural University, to assess the effect of resources conservation practices and nutrient management on yield, yield attributes and economics under wheat crop. The experiment was laid out in split plot design, replicated thrice with three main plot viz. Conventional tillage, Conventional tillage $+30 \%$ rice residue incorporation, Zero tillage $+30 \%$ rice residue retention and four sub plot viz. $100 \%$ of Recommended dose of fertilizer (RDF) through inorganic sources, $75 \%$ of RDF through inorganic sources $+25 \%$ of RDF through organic sources (vermicompost), 50\% of RDF through inorganic sources $+50 \%$ of RDF through organic sources (vermicompost) and $100 \%$ of RDF through inorganic sources + mungbean as green manuring. A preferential influence was found with the resources conservation practices. The results clearly indicated that the wheat crop under zero tillage $+30 \%$ residue retention $\left(\mathrm{M}_{3}\right)$ produced significantly higher grain $\left(47.44 \mathrm{q} \mathrm{ha}^{-1}\right)$ and straw yield $\left(63.55 \mathrm{qha}^{-1}\right)$. Among the sub plot treatments $100 \% \mathrm{RDF}+$ green manuring $\left(\mathrm{S}_{4}\right)$ recorded more grain yield $\left(46.33 \mathrm{q} \mathrm{ha} \mathrm{h}^{-1}\right)$ as compared to other treatments. It was statistically at par with $100 \%$ RDF through inorganic sources. Besides this, the superiority of resource conservation practices was observed over conventional practices in terms of cost saving (₹ $37565 \mathrm{ha}^{-1}$ ) and more efficient use of inputs. Hence, zero tillage with $30 \%$ residue retention could be an economically viable option for wheat cultivation.
\end{abstract}

Keywords: Green manuring, Nutrient management, Resource conservation, Zero tillage

In recent time, farmers become used to with the higher doses of seed, chemical fertilizers, chemical insecticides and weedicides for cultivation of wheat. As a result, the fertility as well as structure of the soil has been disturbed, resulting in the continuous decreasing in the production and productivity. In conventional method, higher use of seed rate per square meter result in competition between plants for nutrition, water, sunlight, there by resulting in decrease of quality and production. Therefore, there is a need for adoption of sustainable agricultural practices for increasing the productivity in wheat to ensure food security for the people. Resource

How to cite this article: Choudhury, S.R., Dipu, D.K., Mandal, N. and Pathak, S.K. (2020). Yield, Yield Attributes and Economics of Wheat as Influenced by Resources Conservation and Nutrient Management Practices. International Journal of Inclusive Development, 6(02): 81-86.

Source of Support: None; Conflict of Interest: None $\infty$ 
conservation is the planned management of natural resources to optimize its use. The main aim behind this is to minimize the energy consumed and also minimize the waste generated during the life cycle of crop production. The resource conserving technologies, involving zero or minimum-tillage improves water and nutrient use efficiency. This is an innovation in residue management to avoid straw burning and help in crop diversification to enhance system productivity and profitability. It allows farmers to reduce inputs, conserve the natural resource base and reduce risk due to both environmental and economic factors (Singh et al. 2011). Furthermore, tillage aims to create a soil environment favourable to plant growth and is defined as physical, chemical or biological soil manipulation to optimize conditions for germination, seedling establishment and crop growth. In recent years interest in conservation tillage systems has increased in response to the need to limit erosion and promote water conservation. No till or zero tillage (ZT) is an important component of conservation agriculture to produce crops at low cost with profound effect on natural resources such as water and soil. It increases organic matter content of soil and microbial biomass as compared to conventional tillage. This system is very effective in minimizing soil and crop residue disturbance, controlling soil evaporation, minimizing erosion losses, sequestering carbon in soil and reducing energy needs. When moisture was limiting there was greater advantage of no-till. However, no-till was always effective with the use of crop residue as mulch (Reddy et al. 2014). The zero tillage with better crop residue management can immensely help in sequestering carbon in degraded lands. An increase of 1 ton of soil carbon pool of degraded land soils may increase crop yield by 20 to $40 \mathrm{~kg}$ $\mathrm{ha}^{-1}$ for wheat (Jat et al. 2014). Therefore, good tillage management and balanced fertilizer application of essential plant nutrients in optimum quantity is essential for a specific soil crop condition. Keep the above facts in mind, this study was carried out to assess the influence of different feasible resource conservation practices and nutrient management options on yield and economics of wheat.

\section{MATERIALS AND METHODS}

A field experiment was carried out to evaluate the feasibility of different management practices in terms of energy use efficiency and economics of wheat. There were three different crop establishment methods as main plot treatments: $M_{1}$ (Wheat: Conventional tillage), $\mathrm{M}_{2}$ (Wheat: Conventional tillage $+30 \%$ residue incorporation), $\mathrm{M}_{3}$ (Wheat: Zero tillage $+30 \%$ residue retention) and four nutrient management as sub plot treatments viz. $S_{1}(100 \%$ of Recommended dose of fertilizer (RDF) through inorganic sources), $S_{2}$ [75\% of RDF through inorganic sources $+25 \% \mathrm{~N}$ of RDF through organic sources (vermicompost)], $\mathrm{S}_{3}$ (50\% of RDF through inorganic sources $+50 \% \mathrm{~N}$ of RDF through organic sources), $\mathrm{S}_{4}\left(\mathrm{~S}_{1}+\right.$ Moong bean as green-manure). Wheat variety $H D-2967$ was sown in the mid of November manually with hand plough at $22 \mathrm{~cm}$ row spacing using seed rate of $100 \mathrm{~kg} \mathrm{ha}^{-1}$. Under zero tillage condition, seeds were sown with the help of hand tyne only, in the $30 \%$ rice residue retaining condition of the field. Recommended dose of fertilizers (RDF) for wheat was $120 \mathrm{~kg} \mathrm{~N}$ $+60 \mathrm{~kg} \mathrm{P}_{2} \mathrm{O}_{5}+40 \mathrm{~kg} \mathrm{~K}_{2} \mathrm{O} \mathrm{ha}^{-1}$. Half of the nitrogen and full dose of phosphorus and potassium were applied through di ammonium phosphate, urea and muriate of potash at basal whereas, rest of the nitrogen applied as urea in two splits. Irrigation was given to crop throughout the crop growth as and when required.

Harvested bundles of wheat plants from each net plot were threshed and winnowed separately. After cleaning, the grain was dried plot wise and then the weight was recorded and consequently grain samples were taken from each plot to determine the moisture content with the help of moisture meter. Finally, the grain yield was calculated at 14 per cent moisture before being subjected to its statistical analysis. The net plot yield was then converted into $\mathrm{q} \mathrm{ha}{ }^{-1}$. Analysis of variance (ANOVA) was done to determine treatment effects (Gomez and Gomez, 1984) using microsoft excel 2007.

\section{RESULTS AND DISCUSSION}

The weather during the period of crop experimentation was close to the normal in respect of relative humidity and maximum temperature (Fig. 1). However, the minimum temperature recorded during month of October to April remained on lower side which is deemed to have lowered the rate of respiration. 


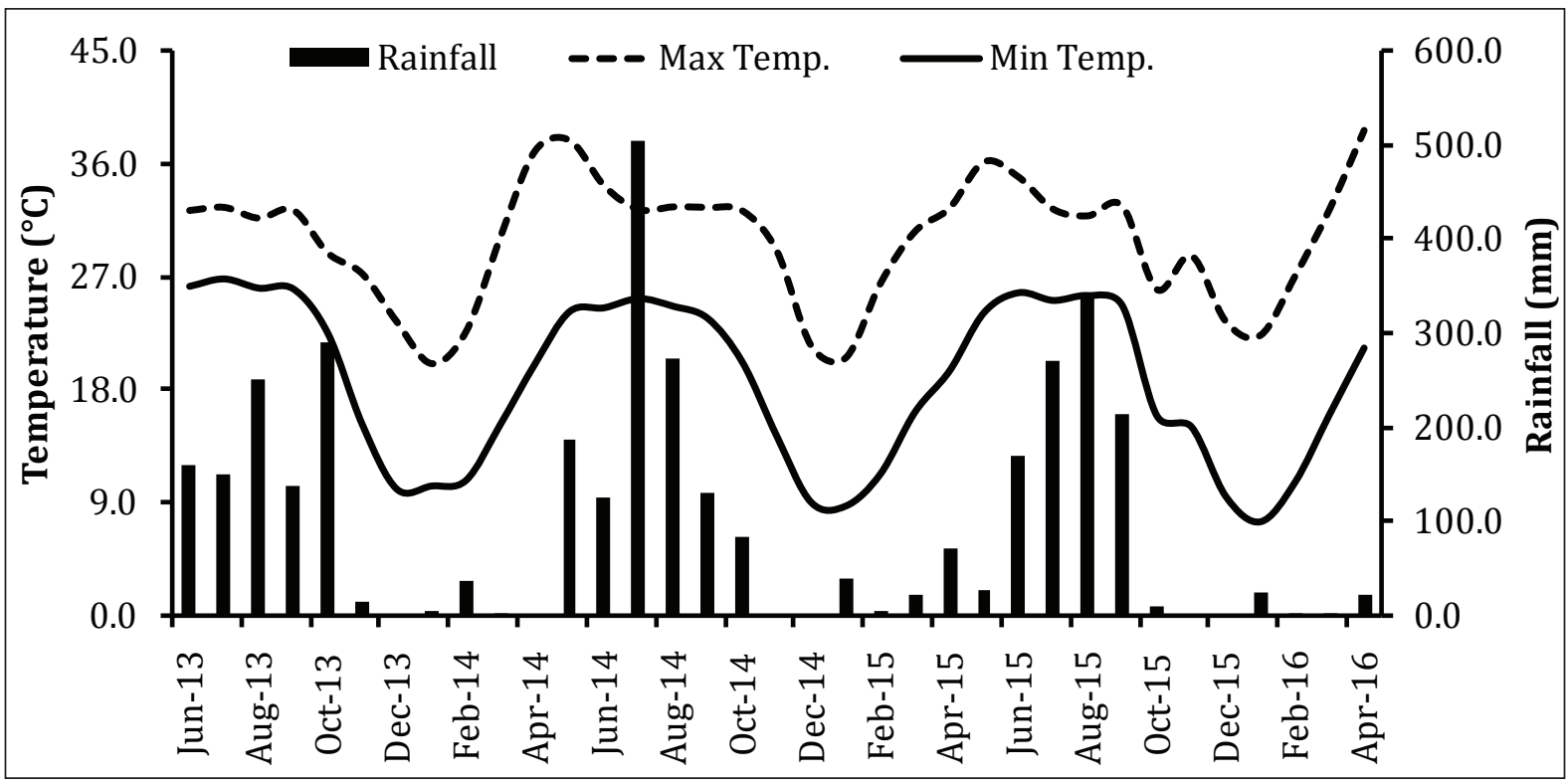

Fig. 1: Monthly mean weather parameter (from June, 2013 to April, 2016)

Table 1: Effect of resources conservation practices and nutrient management on Yield attributes of wheat

\begin{tabular}{|c|c|c|c|c|}
\hline Treatments & Ear head $\mathrm{m}^{-2}$ & Grains / spike & $\begin{array}{l}\text { Filled grains per } \\
\text { spike }\end{array}$ & Test Weight (g) \\
\hline \multicolumn{5}{|l|}{ Resource conservation practices } \\
\hline Conventional tillage $\left(\mathrm{M}_{1}\right)$ & 223.84 & 51.74 & 43.41 & 36.96 \\
\hline Zero tillage $+30 \%$ Residue retention $\left(\mathrm{M}_{3}\right)$ & 257.09 & 54.12 & 45.78 & 37.52 \\
\hline $\mathrm{SEm} \pm$ & 3.63 & 0.31 & 0.31 & 0.24 \\
\hline $100 \%$ inorganic $\left(S_{1}\right)$ & 246.0 & 54.40 & 46.07 & 37.29 \\
\hline $75 \%$ inorganic $+25 \%$ organic $\left(S_{2}\right)$ & 236.8 & 51.60 & 43.27 & 36.90 \\
\hline $50 \%$ inorganic $+50 \%$ organic $\left(\mathrm{S}_{3}\right)$ & 226.3 & 51.47 & 43.13 & 37.33 \\
\hline $100 \%$ inorganic + Green manuring $\left(S_{4}\right)$ & 253.3 & 54.92 & 46.53 & 37.52 \\
\hline $\mathrm{SEm} \pm$ & 3.93 & 0.40 & 0.40 & 0.39 \\
\hline $\mathrm{CD}$ at $5 \%$ & NS & NS & NS & NS \\
\hline
\end{tabular}

Consequently, lowering the loss of photosynthate from sink site and accumulating higher amount of carbohydrate. In case of rainfall pattern, particularly during October to April, it remained below the normal, which is expected to influence the performance of crop receiving limited irrigation.

The two years of experimental data indicated that the effect of resources conservation practices and nutrient management practices have significant influence on number of effective tillers per meter square, grains and filled grains per spike (Table 1). Maximum number of effective tillers (257.09 $\mathrm{m}^{-2}$ ) and grains per spike (54.12) were obtained from $M_{3}$ (Zero tillage wheat $+30 \%$ residue retention and were significantly superior to the rest of the main plot treatments i.e. conventional practices. Basically, zero till soil or minimum disturb soil help in more root length density of the crop, produce greater xylem exudates and transport these towards shoot at faster rates. These features contribute to the maintenance of 
higher chlorophyll levels, enhance fluorescence and photosynthesis rates of the leaves and support more favourable yield attributes i.e. number of effective tillers per meter square of the crop and grains per spike than in more disturb soil. Nutrient management attributed a significant influence on yield attributes like number of effective tillers, grains per spike and filled grains per spike. $100 \%$ inorganic fertilizer along with green manuring $\left(\mathrm{S}_{4}\right)$ recorded highest effective tillers $\left(253.3 \mathrm{~m}^{-2}\right)$, grains per spike (54.92) and filled grains per spike (46.53) as compared to other nutrient management treatments although, it were statistically at par with $100 \%$ inorganic fertilization $\left(S_{1}\right) \cdot 100 \%$ recommended dose of fertilizer through inorganic sources give adequate nutrients quickly as compare to organic substitution of chemical fertilization to the crop. Moreover, extra advantage is derived from green manuring being organic sources in $\mathrm{S}_{4}$ plots. Nitrogen being a constituent of amino acid, nucleotides, nucleic acid, a number of coenzymes, auxin, cytokinins and alkaloids, it includes cell elongation, cell enlargement and cell division (Salisburry and Ross, 1969). These activities in turn activate meristimatic tissues which remain functional for longer periods resulting in better expression of yield and yield attributes and converting more solar energy to productive energy (Kumawat and Bansal, 1996). Test weight of wheat (1000 grain weight) was showed albeit non-significance with respect to different resource conservation and nutrient management practices. Results also revealed that the mean grain yield was significantly influenced by different resource conservation practices and nutrient management practices. Maximum mean grain yield was obtained from the plots where crop was under $\mathrm{M}_{3}$ (zero tillage $+30 \%$ rice residue retention) (47.44 $\mathrm{q} \mathrm{ha}^{-1}$ ) and the grain yield obtained under zero tillage plots was significantly higher than the conventional practices $\left(42.40 \mathrm{q}^{\mathrm{h}} \mathrm{a}^{-}\right.$ $\left.{ }^{1}\right)$ (Table 2). As the yield attributing character was maximum under this $M_{3}$ treatment contributing higher grain yield. Basically, zero till soil or minimum disturb soil help in more root length density of the crop, produce greater xylem exudates and transport these towards shoot at faster rates. These features contribute to the maintenance of higher chlorophyll levels, enhance fluorescence and photosynthesis rates of the leaves and support more favourable yield attributes. Additionally, minimum disturbed soil in zero tillage $\left(\mathrm{M}_{3}\right)$ has a positive effect on the proliferation of roots and thereby, increasing the uptake of plan nutrients from the soil and ultimately grain yield of the crop. Jan and Khan (2002), Khan et al. (2005) stated that the greater spike $\mathrm{m}^{-2}$, grains per spike, and 1000-grain weight may be attributed to the adequate $\mathrm{N}$ availability, which facilitates tillering, and develops more and heavier grains in wheat crop. Significantly higher

Table 2: Effect of resources conservation practices and nutrient management on Yield of wheat

\begin{tabular}{|c|c|c|c|}
\hline Treatments & Grain Yield (q ha-1) & Straw Yield (q ha-1) & Harvest Index (\%) \\
\hline \multicolumn{4}{|l|}{ Resource conservation practices } \\
\hline Conventional tillage $\left(\mathrm{M}_{1}\right)$ & 42.40 & 51.89 & 44.81 \\
\hline Conventional tillage $+30 \%$ residue incorporation $\left(\mathrm{M}_{2}\right)$ & 43.80 & 56.31 & 43.42 \\
\hline Zero tillage $+30 \%$ Residue retention $\left(\mathrm{M}_{3}\right)$ & 47.44 & 63.55 & 42.49 \\
\hline SEm \pm & 0.55 & 2.86 & 1.36 \\
\hline $\mathrm{CD}$ at $5 \%$ & 1.53 & 7.94 & NS \\
\hline $100 \%$ inorganic $\left(S_{1}\right)$ & 46.15 & 58.15 & 44.35 \\
\hline $75 \%$ inorganic $+25 \%$ organic $\left(S_{2}\right)$ & 43.69 & 56.13 & 43.78 \\
\hline $50 \%$ inorganic $+50 \%$ organic $\left(S_{3}\right)$ & 42.01 & 55.07 & 43.32 \\
\hline $100 \%$ inorganic + Green manuring $\left(S_{4}\right)$ & 46.33 & 59.46 & 42.86 \\
\hline SEm \pm & 0.972 & 0.318 & 0.420 \\
\hline
\end{tabular}


grain yield was recorded from the crop sown with $100 \%$ inorganic fertilization and green manuring $\left(\mathrm{S}_{4}\right)$ than the crop sown with other sub plot treatments although, this treatment was found to be statistically at par with $100 \%$ inorganic fertilization. The yield ascribing character was maximum under this $S_{4}$ treatment resulting higher grain yield. These results were in close agreement with the earlier studies (Coventry et al. 2011; Jat et al. 2014: Usman et al. 2014).

Analysed data on net return revealed that the effect due to resource conservation practices and nutrient management practices were statistically significant, whereas their interaction effect was non-significant (Table 3). The highest net return was recorded from $\mathrm{M}_{3}$ (zero tillage $+30 \%$ rice residue retention) ( $₹ 30065 \mathrm{ha}^{-1}$ ), which in turn was significantly superior to the rest of the resources conservation practices. This may be due to the fact that less tillage of the soil reduces labour, fuel, irrigation and machinery costs. No-till can increase yield because of higher water infiltration and storage capacity, and less erosion. Generally, non-requirement of preparatory tillage unlike conventional tillage is the reason of lowering cost of cultivation of zero tillage besides higher yield. Therefore, net return will automatically increase under this treatment. The maximum net return was also recorded from the crop raised with $100 \%$ inorganic fertilization was significantly superior to net return of the crop raised with other sub plot treatments although, it was statistically at par with $100 \%$ inorganic fertilization with green manuring. Maximum gross return was observed under this treatment contribute to maximum net return. These are also in close agreement with findings of Erenstein et al. (2008).

\section{CONCLUSION}

Recently there has been a rapid growing interest in adopting system of Zero tillage in wheat as the most potential tool for enhancing the crop production. In this way Zero tillage technique is not only a reliable way of obtaining fairly high productivity but also ensure stability in the agricultural production system for its long term sustainability through the effective and efficient utilization of resources i.e., strategic inputs and also its increase production capabilities in an environmentally sound manner which in turn will reduce the dependency on external costly inputs. The superiority of resource conservation practices over conventional practices in terms of cost saving and more efficient use of inputs has been proved. Thus, it can be concluded that wider adoption of resource conservation practices has long run benefits in terms of conserving natural resources, higher production, saving cost on cultivation and improving the climatic conditions in the region.

Table 3: Effect of resources conservation practices and nutrient management on economics of wheat

\begin{tabular}{|c|c|c|c|c|}
\hline \multirow{2}{*}{ Treatments } & Cost of cultivation & Gross Return & Net Return & \multirow{2}{*}{$-B: C$} \\
\hline & \multicolumn{3}{|c|}{$\left(₹ h^{-1}\right)$} & \\
\hline \multicolumn{5}{|l|}{ Resource conservation practices } \\
\hline Conventional tillage $\left(\mathrm{M}_{1}\right)$ & 36707 & 57970 & 21262 & 0.984 \\
\hline Conventional tillage $+30 \%$ residue incorporation $\left(\mathrm{M}_{2}\right)$ & 37707 & 60692 & 22985 & 1.008 \\
\hline Zero tillage $+30 \%$ Residue retention $\left(\mathrm{M}_{3}\right)$ & 36447 & 66512 & 30065 & 1.30 \\
\hline $\mathrm{SEm} \pm$ & - & 876.46 & 876.46 & 0.03 \\
\hline $\mathrm{CD}$ at $5 \%$ & - & 2433.45 & 2433.45 & 0.084 \\
\hline \multicolumn{5}{|l|}{ Nutrient management } \\
\hline $100 \%$ inorganic $\left(S_{1}\right)$ & 29396 & 63600 & 34204 & 1.16 \\
\hline $75 \%$ inorganic $+25 \%$ organic $\left(S_{2}\right)$ & 39216 & 60594 & 21377 & 1.07 \\
\hline $50 \%$ inorganic $+50 \%$ organic $\left(S_{3}\right)$ & 49036 & 58534 & 9498 & 1.01 \\
\hline $100 \%$ inorganic + Green manuring $\left(S_{4}\right)$ & 30166 & 64171 & 34004 & 1.12 \\
\hline SEm \pm & - & 1047.9 & 1047.9 & 0.035 \\
\hline $\mathrm{CD}$ at $5 \%$ & - & 2604 & 2201.55 & 0.074 \\
\hline \multicolumn{5}{|l|}{ Interaction $\mathrm{M} \times \mathrm{S}$} \\
\hline SEm \pm & - & 2604.76 & 2604.76 & 0.089 \\
\hline $\mathrm{CD}$ at $5 \%$ & - & NS & NS & NS \\
\hline
\end{tabular}




\section{REFERENCES}

Coventry, D.R., Poswal, R.S., Yadav, A., Gupta, R.K., Gill, S.C., Chhokar, R.S., Kumar, V., Sharma, R.K., Kumar, A., Mehta, S.G.L. and Cummins, J.A. 2011. Effect of tillage and nutrient management on wheat productivity and quality in Haryana, India. Field Crops Research, 123: 234-240.

Erenstein, O. and Laxmi, V. 2008. Zero tillage impacts in India's rice-wheat systems: A review. Soil and Tillage Research, 100: 1-14.

Gomez, A.K. and Gomez, A.A. 1984. Statistical Procedures for Agricultural Research. New York: John Wiley \& Sons.

Jan, M.T. and Khan, S. 2002. Response of wheat yield components to type of $\mathrm{N}$ fertilizer, their levels and application time. Pakistan Journal of Biological Science, 3: 1227-1230.

Jat, R.K., Sapkota, T.B., Singh, R.G., Jat, M.L., Kumar, M. and Gupta, R.K. 2014. Seven years of conservation agriculture in a rice-wheat rotation of Eastern Gangetic Plains of South Asia: Yield trends and economic profitability. Field Crops Research, 164: 199-201.

Khan, A., Jan, A. and Alam, S. 2005. Effect of nitrogen and seed size on maize crop II: Yield and yield components. Journal of Agriculture E Social Sciences, 1: 18-23.
Kumawat, S.M. and Bansal, K.N. 1996. Residual effect of sulphur sources in combination with nitrogen and plant growth regulator on sorghum. Indian Journal of Agronomy, 41: 647-649.

Reddy, D.D., Kushwha, S., Srivastva, S. and Khamparia, R.S. 2014. Long-term wheat residue management and supplementary nutrient input effects on phosphorus fractions and adsorption behavior in a Vertisol. Communications in Soil Science and Plant Analysis, 45: 541-545.

Salisburry, B.F. and Ross, C. 1996. Plant physiology, Wordsworth publishing company, Belmonst California, pp. 673-670.

Singh, N.P., Singh, R.P., Kumar, R., Vashist, A.K., Khan, F. and Varghese, N. 2011. Adoption of resource conservation technologies in Indo-gangetic plains of India: scouting for profitability and efficiency. Agricultural Economics Research, 24:15-24.

Usman, K., Khan, E.A., Yazdan, F., Khan, N., Rashid, A. and Uddin, S. 2014. Short response of spring wheat to tillage, residue management and split nitrogen application in a rice-wheat system. Journal of Integrative Agriculture, 13: 2625-2633. 